\title{
Internal elements of the millipede, Chamberlinius hualienensis Wang (Polydesmida: Paradoxosomatidae)
}

\author{
Kazuyo NAKamura, ${ }^{1}$ Junsei TAIRA ${ }^{2, *}$ and Yoshiko Higa ${ }^{3}$ \\ ${ }^{1}$ Okinawa Prefectural Enterprise Bureau, Water Quality Control Office; Nishihara-cho, Okinawa 903-0103, Japan \\ ${ }^{2}$ Okinawa Industrial Technology Center; Uruma, Okinawa 904-2234, Japan \\ ${ }^{3}$ Okinawa Millipede Research Laboratory; Kochinda-cho, Okinawa 901-0402, Japan
}

(Received 12 August 2004; Accepted 2 February 2005)

\begin{abstract}
The concentrations of 54 elements of the millipede Chamberlinius hualienensis and the soil including leaf litters were examined using inductively coupled plasma atomic emission spectrometry (ICP-AES) and inductively coupled plasma mass spectrometry (ICP-MS). In all the millipedes, the Ca concentration derived from the calcium carbonate in the exoskeleton was the highest, at an average of $76 \mu \mathrm{g} / \mathrm{mg}$-weight, and the other major elements were the following: $\mathrm{Mg}$, $\mathrm{K}, \mathrm{Na}, \mathrm{Fe}, \mathrm{Al}, \mathrm{Cu}, \mathrm{Zn}, \mathrm{Sr}, \mathrm{Ba}, \mathrm{Mn}$ and $\mathrm{Ti}$ (>1 ng/mg-weight), whereas $\mathrm{Ni}, \mathrm{Cr}, \mathrm{V}, \mathrm{Ga}, \mathrm{Mo}, \mathrm{Co}, \mathrm{Cd}$, etc. were at trace levels. Interestingly, the contents of $\mathrm{Ca}, \mathrm{Mg}, \mathrm{K}, \mathrm{Na}, \mathrm{Zn}, \mathrm{Sr}, \mathrm{V}, \mathrm{Co}, \mathrm{Ag}$, and $\mathrm{Sc}$ in larvae were higher than in adult millipedes. Although the heavy metal contents, in the order of $\mathrm{Cu}>\mathrm{Pb}>\mathrm{Cd}$, were similar to those of other invertebrates such as chilopoda, collembola, and carabidae, there was a high concentration of $\mathrm{Cu}$ in the millipedes. The other internal metals, As and Ag, were dependent on the soil concentrations in the habitat. $\mathrm{Zn}$ concentrations at sampling sites were different, but a constant level was maintained in the millipede. The results suggest that millipedes may provide information on the accumulation or regulation mechanism in the body for certain hazardous heavy metals. The $\mathrm{C} 1$ chondrite normalization pattern for lanthanoid series elements in both the millipede and soil indicated that the environmental habitats were well protected from pollution. The characteristics of internal elements and metal accumulation in the millipede in terms of relation to the habitat would be useful information for environmental pollution studies.
\end{abstract}

Key words: Millipede; Chamberlinius hualienensis; ICP-AES; ICP-MS; element

\section{INTRODUCTION}

Soil invertebrates have often been used as bioindicators for environmental pollution caused by heavy metals such as $\mathrm{Cd}, \mathrm{Cu}, \mathrm{Pb}$, and $\mathrm{Zn}$ because their habitats are in close contact with contaminants in soils. The accumulation levels of heavy metals in earthworms are commonly used as risk assessments for environments or invertebrates eating animals (Roberts and Johnson, 1978; Ireland, 1979; Beyer et al., 1985; Heikens et al., 2001). Millipedes inhabit the same areas as other invertebrates and they are distributed widely around the world.

Millipedes discharge odorous secretions that cause headaches and unpleasant feelings for humans (Eisner et al., 1978; Mori et al., 1994;
Noguchi et al., 1997a). Recent studies demonstrated that the odorous compounds are different according to sex and habitat (Noguchi et al., 1997b; Taira and Arakaki, 2002; Taira et al., 2003). Such studies for active compounds in the millipede have elucidated much detailed information. However, knowledge regarding the essential elements or heavy metals is only provided for hazardous heavy metals like $\mathrm{Cu}, \mathrm{Cd}, \mathrm{Pb}$, and $\mathrm{Zn}$, and only for a few species of millipedes, and the amount of physiological data is yet insufficient (Beyer et al., 1985; Hunter et al., 1987; Gräff et al., 1997).

In Okinawa, Chamberlinius hualienensis Wang belongs to Polydesmida: Paradoxosomatidae migrates during the rainy season (from May to the end of June) and/or during the reproductive period (Higa et al., 1992). The millipede is found in damp

* To whom correspondence should be addressed at: E-mail: tairajns@pref.okinawa.jp DOI: $10.1303 /$ aez.2005.283 
areas and feeds on fallen or withered leaves in the soil. Its lifecycle is one year, and therefore slight changes in the environment over the short-term period are reflected in the body. In the present study, the internal elements of the millipede collected from non-polluted fields were examined by ICPAES and ICP-MS.

\section{MATERIALS AND METHODS}

A mix standard (U, Be, Bi, Ce, Co, In, $\mathrm{Pb}, \mathrm{Mg}$, $\mathrm{Ni}$ ) and other authentic elements were obtained from AccuStandard Inc. (CT, USA) and Wako Pure Chemical Industries, Ltd. (Osaka, Japan). These were used to make calibration curves. Reagent grade water with a resistance of $18.2 \mathrm{M} \Omega$ made using a Milli-Q water purification system (Millipore Co., MA, USA) was used for all experimental preparations. Nitric acid, hydrogen peroxide and ethanol were of analytical reagent grade.

In the autumn of 2000, adults and 7th stage larvae of $C$. hualienensis were collected at Ginowan and Haebaru in Okinawa, Japan. Each insect was weighed and its sex was determined by the presence (male) or absence (female) of gonads. The millipedes were defecated for at least $1 \mathrm{~d}$, and then individually preserved in $70 \%$ ethanol until measurement. The adult millipedes collected at Ginowan were $237 \pm 45 \mathrm{mg}$ (mean \pm S.D., $n=3$ ). The Haebaru samples were $190 \mathrm{mg}$ (mean, $n=2$ ) for adults and $75 \pm 9 \mathrm{mg}$ (mean \pm S.D., $n=3$ ) for 7 th stage larvae. Soil samples of $1 \mathrm{~cm}$ in depth from surface including leaf litters as the possible food source of the millipedes were collected at five points in each sampling area. The soil samples were mixed and air-dried. Pebbles were filtered out and the soil samples were then ground in an agate mortar.

Each millipede together with the ethanol solution was transferred into a Teflon beaker, and $5 \mathrm{ml}$ of nitric acid $(60 \%)$ was added. The mixture was covered with a watch glass and then carefully heated until the brown-colored gas was dissipated. After cooling the sample solution, the addition of $2 \mathrm{ml}$ hydrogen peroxide (30\%) completely decomposed the sample. The soil sample $(500 \mathrm{mg})$ was broken down similarly to the millipede. Finally, all samples were adjusted to $50 \mathrm{ml}$ with nitric acid (1\%) for measurement using ICP-AES (Shimadzu ICPS-7000, Shimadzu) and ICP-MS (HP-4500 se-
Table 1. Analytical conditions of ICP-AES and ICP-MS

\begin{tabular}{|c|c|}
\hline \multicolumn{2}{|l|}{ ICP-AES } \\
\hline \multicolumn{2}{|l|}{ Plasma conditions } \\
\hline RF frequency & $40.68 \mathrm{MHz}$ \\
\hline RF power & $1.0 \mathrm{~kW}$ \\
\hline Coolant gas flow rate & $8.0 \mathrm{l} / \mathrm{min} \mathrm{Ar}$ \\
\hline Auxiliary gas flow rate & $0.6 \mathrm{l} / \mathrm{min} \mathrm{Ar}$ \\
\hline Carrier gas flow rate & $0.6 \mathrm{l} / \mathrm{min} \mathrm{Ar}$ \\
\hline Observation height & $8 \mathrm{~mm}$ \\
\hline Nebulizer & Pyrex glass, coaxial type \\
\hline Sample uptake rate & $1.5 \mathrm{ml} / \mathrm{min}$ \\
\hline \multicolumn{2}{|l|}{ ICP-MS } \\
\hline \multicolumn{2}{|l|}{ Plasma conditions } \\
\hline RF frequency & 27.12 MHz \\
\hline RF power & $1.5 \mathrm{~kW}$ \\
\hline Plasma gas flow rate & $17 \mathrm{l} / \mathrm{min} \mathrm{Ar}$ \\
\hline Auxiliary gas flow rate & $1.0 \mathrm{l} / \mathrm{min} \mathrm{Ar}$ \\
\hline Carrier gas flow rate & $1.23 \mathrm{l} / \mathrm{min} \mathrm{Ar}$ \\
\hline \multicolumn{2}{|l|}{ Sampling conditions } \\
\hline Sampling depth & $8 \mathrm{~mm}$ \\
\hline Sampling cone & Nickel \\
\hline Skimmer cone & Nickel \\
\hline Nebulizer & PEEK, Babington type \\
\hline Sample uptake rate & $0.4 \mathrm{ml} / \mathrm{min}$ \\
\hline \multicolumn{2}{|l|}{ Data acquisition } \\
\hline Data point & 3 points/peak \\
\hline Number of scan & 100 times \\
\hline
\end{tabular}

ries, Hewlett Packard).

The concentrations of 49 elements in the millipede were determined using the ICP-MS with ${ }^{72} \mathrm{Ge}$ $(10 \mathrm{ppb})$ and ${ }^{103} \mathrm{Rh}(10 \mathrm{ppb})$ as the internal standard. ICP-AES measurement with an internal standard Y (50 ppb) was applied to obtain accurate data for $\mathrm{Ca}, \mathrm{Mg}, \mathrm{K}, \mathrm{Na}$, and $\mathrm{Fe}$ because they are affected by interfering ions such as $\mathrm{ArO}^{+}, \mathrm{ArOH}^{+}$, and $\mathrm{CO}_{2}{ }^{+}$. The detailed operational conditions of the equipment are summarized in Table 1. Each elemental concentration in the sample was determined by three times measurements.

\section{RESULTS AND DISCUSSION}

The concentrations of 54 elements in the millipedes and soil samples were examined using ICPAES and ICP-MS (Table 2). In the millipedes, Ca (av. $76 \mu \mathrm{g} / \mathrm{mg}$-weight) occupied ca. $19 \%$ of the body weight, derived from the calcium carbonate in the exoskeleton (Hattori and Moriya, 1987). The other major elements having values larger than $1 \mathrm{ng} / \mathrm{mg}$-weight in all specimens were the follow- 
Table 2. Elemental contents in Chamberlinius hualienensis and soil

\begin{tabular}{|c|c|c|c|c|c|c|c|c|}
\hline \multirow{3}{*}{$\mathrm{No}^{\mathrm{a}}$} & \multirow{3}{*}{ Element } & \multirow{3}{*}{$\begin{array}{l}\text { Wavelength } \\
(\mathrm{nm})\end{array}$} & \multirow{3}{*}{$m / z$} & \multicolumn{3}{|c|}{$\begin{array}{c}\text { Millipede } \\
\text { [ng/mg-weight] }\end{array}$} & \multicolumn{2}{|c|}{$\begin{array}{c}\text { Soil } \\
{[\mathrm{ng} / \mathrm{mg}]}\end{array}$} \\
\hline & & & & \multirow{2}{*}{$\begin{array}{c}\text { Ginowan } \\
\begin{array}{l}\text { Adult } \\
(n=3)\end{array}\end{array}$} & \multicolumn{2}{|c|}{ Haebaru } & \multirow[b]{2}{*}{ Ginowan } & \multirow[b]{2}{*}{ Haebaru } \\
\hline & & & & & $\begin{array}{l}\text { Adult } \\
(n=2)\end{array}$ & $\begin{array}{l}\text { th stage larva } \\
\qquad(n=3)\end{array}$ & & \\
\hline 1 & $\mathrm{Ca}$ & 317.933 & & 61,912 & 60,245 & 101,372 & 25,280 & 46,819 \\
\hline 2 & $\mathrm{Mg}$ & 279.553 & & 1,391 & 1,350 & 2,609 & 3,070 & 6,781 \\
\hline 3 & $\mathrm{~K}$ & 766.491 & & 1,283 & 1,045 & 1,920 & 3,331 & 4,593 \\
\hline 4 & $\mathrm{Na}$ & 589.592 & & 504 & 462 & 819 & 1,272 & 1,001 \\
\hline 5 & $\mathrm{Fe}$ & 259.940 & & 120 & 305 & 252 & 24,186 & 16,852 \\
\hline 6 & $\mathrm{Al}$ & & 27 & 101 & 174 & 225 & 22,245 & 14,526 \\
\hline 7 & $\mathrm{Cu}$ & & 65 & 115 & 93 & 168 & 20 & 17 \\
\hline 8 & $\mathrm{Zn}$ & & 66 & 117 & 89 & 188 & 425 & 85 \\
\hline 9 & $\mathrm{Sr}$ & & 86 & 18 & 20 & 37 & 22 & 23 \\
\hline 10 & $\mathrm{Ba}$ & & 137 & 18 & 6.9 & 27 & 74 & 76 \\
\hline 11 & $\mathrm{Mn}$ & & 55 & 7.2 & 14 & 20 & 329 & 272 \\
\hline 12 & $\mathrm{Ti}$ & & 47 & 5.6 & 14 & 24 & 203 & 220 \\
\hline 13 & As & & 75 & 2.5 & 0.58 & 1.3 & 12 & 4.2 \\
\hline 14 & $\mathrm{~Pb}$ & & 208 & 0.92 & 1.9 & 0.92 & 24 & 15 \\
\hline 15 & $\mathrm{Ni}$ & & 60 & 0.53 & 0.73 & 0.92 & 21 & 18 \\
\hline 16 & $\mathrm{Cr}$ & & 53 & 0.40 & 0.82 & 0.64 & 49 & 21 \\
\hline 17 & $\mathrm{~V}$ & & 51 & 0.34 & 0.51 & 0.72 & 41 & 33 \\
\hline 18 & $\mathrm{Ga}$ & & 69 & 0.57 & 0.20 & 0.92 & 7.6 & 6.1 \\
\hline 19 & $\mathrm{Li}$ & & 7 & 0.10 & 0.34 & 0.41 & 25 & 23 \\
\hline 20 & $\mathrm{Ce}$ & & 140 & 0.16 & 0.29 & 0.23 & 39 & 17 \\
\hline 21 & $\mathrm{Zr}$ & & 90 & 0.16 & 0.19 & 0.23 & 6.6 & 6.1 \\
\hline 22 & Mo & & 95 & 0.13 & 0.22 & 0.16 & 0.64 & 0.69 \\
\hline 23 & Co & & 59 & 0.12 & 0.14 & 0.23 & 4.7 & 5.8 \\
\hline 24 & $\mathrm{Y}$ & & 89 & 0.10 & 0.14 & 0.12 & 28 & 6.1 \\
\hline 25 & $\mathrm{La}$ & & 139 & 0.089 & 0.15 & 0.14 & 20 & 7.8 \\
\hline 26 & $\mathrm{Nd}$ & & 146 & 0.082 & 0.15 & 0.12 & 20 & 8.2 \\
\hline 27 & $\mathrm{Cd}$ & & 111 & 0.079 & 0.072 & 0.11 & 0.89 & 0.35 \\
\hline 28 & $\mathrm{Cs}$ & & 133 & 0.062 & 0.051 & 0.036 & 2.2 & 1.9 \\
\hline 29 & $\mathrm{Pd}$ & & 105 & 0.043 & 0.053 & 0.068 & 0.39 & 0.14 \\
\hline 30 & $\operatorname{Pr}$ & & 141 & 0.022 & 0.033 & 0.028 & 4.7 & 1.9 \\
\hline 31 & $\mathrm{Gd}$ & & 157 & 0.017 & 0.029 & 0.022 & 4.3 & 1.6 \\
\hline 32 & $\mathrm{Ag}$ & & 107 & 0.049 & 0.073 & 0.36 & 0.062 & 0.33 \\
\hline 33 & $\mathrm{Nb}$ & & 93 & 0.0015 & 0.017 & 0.0018 & 0.20 & 0.12 \\
\hline 34 & Sn & & 118 & $<0.023^{\mathrm{b}}$ & 0.11 & $<0.013^{\mathrm{b}}$ & 0.40 & 0.055 \\
\hline 35 & $\mathrm{Sm}$ & & 147 & $<0.022^{\mathrm{b}}$ & 0.027 & 0.022 & 4.1 & 1.7 \\
\hline 36 & $\mathrm{U}$ & & 238 & $<0.0091^{\mathrm{b}}$ & 0.023 & 0.014 & 1.5 & 0.54 \\
\hline 37 & $\mathrm{Sc}$ & & 45 & 0.019 & $<0.010^{\mathrm{b}}$ & 0.044 & 7.0 & 4.7 \\
\hline 38 & Dy & & 163 & $<0.015^{\mathrm{b}}$ & 0.018 & 0.017 & 3.7 & 1.2 \\
\hline 39 & $\mathrm{Er}$ & & 166 & $<0.011^{\mathrm{b}}$ & 0.012 & 0.0085 & 2.0 & 0.55 \\
\hline 40 & $\mathrm{Se}$ & & 82 & $<0.18^{\mathrm{b}}$ & $<0.18^{\mathrm{b}}$ & 0.11 & 0.46 & 0.34 \\
\hline 41 & $\mathrm{Eu}$ & & 153 & $<0.0082^{\mathrm{b}}$ & $<0.0082^{\mathrm{b}}$ & 0.0051 & 0.95 & 0.36 \\
\hline 42 & $\mathrm{Tl}$ & & 205 & $<0.013^{\mathrm{b}}$ & $<0.013^{\mathrm{b}}$ & $<0.0078^{b}$ & 0.21 & 0.091 \\
\hline 43 & $\mathrm{Te}$ & & 125 & $<0.0061^{\mathrm{b}}$ & $<0.0061^{\mathrm{b}}$ & $<0.0036^{\mathrm{b}}$ & 0.042 & 0.010 \\
\hline 44 & $\mathrm{Yb}$ & & 172 & $<0.011^{\mathrm{b}}$ & $<0.011^{\mathrm{b}}$ & $<0.0064^{\mathrm{b}}$ & 1.4 & 0.45 \\
\hline 45 & $\mathrm{Be}$ & & 9 & $<0.023^{\mathrm{b}}$ & $<0.023^{\mathrm{b}}$ & $<0.013^{\mathrm{b}}$ & 0.53 & 0.41 \\
\hline 46 & In & & 115 & $<0.011^{\mathrm{b}}$ & $<0.011^{\mathrm{b}}$ & $<0.0064^{\mathrm{b}}$ & 0.031 & 0.029 \\
\hline 47 & $\mathrm{~Tb}$ & & 159 & $<0.0082^{b}$ & $<0.0082^{\mathrm{b}}$ & $<0.0048^{\mathrm{b}}$ & 0.64 & 0.22 \\
\hline
\end{tabular}


Table 2. (Continued)

\begin{tabular}{|c|c|c|c|c|c|c|c|c|}
\hline \multirow{3}{*}{$\mathrm{No}^{\mathrm{a}}$} & \multirow{3}{*}{ Element } & \multirow{3}{*}{$\begin{array}{l}\text { Wavelength } \\
(\mathrm{nm})\end{array}$} & \multirow{3}{*}{$m / z$} & \multicolumn{3}{|c|}{$\begin{array}{c}\text { Millipede } \\
\text { [ng/mg-weight] }\end{array}$} & \multicolumn{2}{|c|}{$\begin{array}{c}\text { Soil } \\
{[\mathrm{ng} / \mathrm{mg}]}\end{array}$} \\
\hline & & & & \multirow{2}{*}{$\begin{array}{c}\text { Ginowan } \\
\text { Adult } \\
(n=3)\end{array}$} & \multicolumn{2}{|c|}{ Haebaru } & \multirow[b]{2}{*}{ Ginowan } & \multirow[b]{2}{*}{ Haebaru } \\
\hline & & & & & $\begin{array}{l}\text { Adult } \\
(n=2)\end{array}$ & $\begin{array}{l}\text { 7th stage larva } \\
\qquad(n=3)\end{array}$ & & \\
\hline 48 & Ho & & 165 & $<0.0088^{\mathrm{b}}$ & $<0.0088^{\mathrm{b}}$ & $<0.0051^{\mathrm{b}}$ & 0.74 & 0.21 \\
\hline 49 & $\mathrm{Tm}$ & & 169 & $<0.0098^{\mathrm{b}}$ & $<0.0098^{\mathrm{b}}$ & $<0.0058^{\mathrm{b}}$ & 0.25 & 0.075 \\
\hline 50 & $\mathrm{Ta}$ & & 181 & $<0.029^{\mathrm{b}}$ & $<0.029^{\mathrm{b}}$ & $<0.017^{\mathrm{b}}$ & $<0.013^{\mathrm{b}}$ & $<0.013^{\mathrm{b}}$ \\
\hline 51 & W & & 182 & $<0.11^{\mathrm{b}}$ & $<0.11^{\mathrm{b}}$ & $<0.063^{\mathrm{b}}$ & $<0.047^{\mathrm{b}}$ & $<0.047^{\mathrm{b}}$ \\
\hline 52 & $\mathrm{Pt}$ & & 195 & $<0.019^{\mathrm{b}}$ & $<0.019^{b}$ & $<0.011^{\mathrm{b}}$ & $<0.0084^{b}$ & $<0.0084^{b}$ \\
\hline 53 & $\mathrm{Au}$ & & 197 & $<0.081^{\mathrm{b}}$ & $<0.081^{\mathrm{b}}$ & $<0.048^{\mathrm{b}}$ & $<0.035^{\mathrm{b}}$ & $<0.035^{\mathrm{b}}$ \\
\hline 54 & $\mathrm{Bi}$ & & 209 & $<0.024^{\mathrm{b}}$ & $<0.024^{\mathrm{b}}$ & $<0.014^{\mathrm{b}}$ & 0.16 & 0.17 \\
\hline
\end{tabular}

${ }^{a}$ Elements No. 1-5 were analyzed with ICP-AES and the others were obtained from ICP-MS.

${ }^{\mathrm{b}}$ Values indicate less than limit of quantitation.

ing: $\mathrm{Mg}, \mathrm{K}, \mathrm{Na}, \mathrm{Fe}, \mathrm{Al}, \mathrm{Cu}, \mathrm{Zn}, \mathrm{Sr}, \mathrm{Ba}, \mathrm{Mn}$, and Ti. On the other hand, 16 elements such as $\mathrm{Ni}, \mathrm{Cr}, \mathrm{V}$, $\mathrm{Ga}, \mathrm{Mo}, \mathrm{Co}$, and Cd were only present at trace levels $(<1 \mathrm{ng} / \mathrm{mg}$-weight), and the concentrations of $\mathrm{Be}$, In, Tb, Ho, Tm, Ta, W, Pt, Au, and Bi were below the limit of quantitation. Generally, the major elements except for $\mathrm{Al}, \mathrm{Sr}, \mathrm{Ba}, \mathrm{Ti}$ and the trace elements of Mo and Co are considered essential elements for almost all insects, but the physiological function of each metal is not yet understood (Bowen, 1979). Interestingly, the contents of $\mathrm{Ca}$, $\mathrm{Mg}, \mathrm{K}, \mathrm{Na}, \mathrm{Zn}, \mathrm{Sr}, \mathrm{V}, \mathrm{Co}, \mathrm{Ag}$, and $\mathrm{Sc}$ in the larvae were higher than those in adult millipedes. Of these elements, $\mathrm{Ca}$ is a major element of the exoskeleton, thus other elements also may be required for developing the larvae with exfoliation.

Environmental pollution studies in the field have been widely conducted using terrestrial invertebrates as the biological indicator (Ireland, 1979; Beyer et al., 1985; Hunter et al., 1987; Van Straalen and Van Wensem, 1986; Rabitsch, 1995). The hazardous heavy metal concentrations in the millipedes were in the order of $\mathrm{Cu}>\mathrm{Pb}>\mathrm{Cd}$, which is similar to other invertebrates such as chilopoda, collembola and carabidae (Rabitsch, 1995). In particular, $\mathrm{Cu}$ was found at a remarkably high concentration in the millipede; for example, the $\mathrm{Cu}$ content for dry-body weight was 7-, 3- and 32-fold higher than that for chilopoda, collembola and carabidae, respectively. A similar phenomenon was also observed in other species of millipede (Beyer et al., 1985; Rabitsch, 1995). Interestingly, the $\mathrm{Cu}$ and $\mathrm{Pb}$ concentrations in the soil at both sampling sites were close, but the amount of $\mathrm{Cu}$ accumulated was more than 100 -folds that of the $\mathrm{Pb}$ in the millipedes, and the internal concentration of $\mathrm{Cu}$ was 4-11 times higher than that of the soil. On the other hand, the concentrations of $\mathrm{Cr}, \mathrm{Ni}$, and $\mathrm{As}$ in the body were $1 / 100-1 / 10$ of the soil concentrations. As concentration in the Ginowan soil sample was three times higher than that of the Haebaru soil sample, the difference in environmental habitat was well reflected in the millipedes of both sampling sites. A similar phenomenon was also seen in the case of Ag. The results suggest that the millipedes may provide information on the accumulation mechanism in the body for certain toxic metals. Such physiological features of the millipede would be a useful index environmental pollution.

The $\mathrm{Zn}$ concentration in the soil from Ginowan was approximately five times higher than that of the Haebaru sample, whereas all millipedes from both habitats had nearly similar concentrations. $\mathrm{Zn}$ is an essential element for various physiological functions related to metabolism. Heikens et al. (2001) reported that $\mathrm{Zn}$ is maintained at a constant level in invertebrates, independent of the soil concentration. The millipede also maintains $\mathrm{Zn}$ in a range of $77-205 \mathrm{ng} / \mathrm{mg}$-weight as an essential element in the body.

Recently, lanthanoid series elements such as Ce, $\mathrm{Pr}$, and $\mathrm{Nb}$ are used as raw materials for industrial products such as glass stains, permanent magnets and condensers, which then make their ways into 


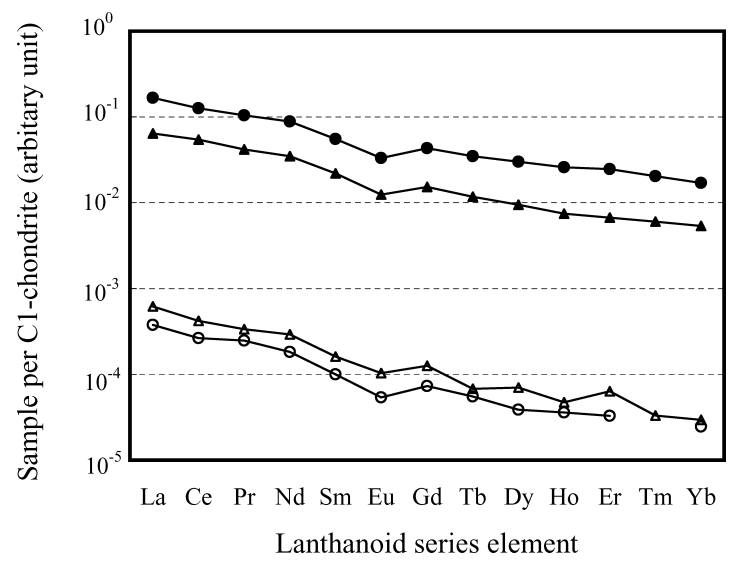

Fig. 1. C1 chondrite normalized lanthanoid series element patterns in the millipede and soil. Each point is expressed as an average of the values obtained from the millipedes $(O)$ and soil $(\bullet)$ at Ginowan, or the millipedes $(\triangle)$ and soil $(\Delta)$ at Haebaru.

the environment. It is expected that the mass release of such potent toxic elements may cause environmental destruction (Kawasaki et al., 1998). The lanthanoid series elements originate from meteorites and elements having even atomic numbers are more abundant than those of the adjoining odd atomic number by the Oddo-Harkins rule, which must be satisfied when the environment is well protected from pollution. The data are usually normalized by each lanthanoid series element in the $\mathrm{C} 1$ chondrite and are often applied for environmental assessment (Teranishi et al., 2003). As shown in Fig. 1, the $\mathrm{C} 1$ chondrite normalized lanthanoid series element patterns for both the millipede and soil sample were clearly expressed as decline lines accompanied by an increase in the atomic number. The results demonstrate that the environmental habitats were well protected from pollution.

In conclusion, it was determined for the first time that there are 54 elements in the millipede Chamberlinius hualienensis. Ca was the highest concentration, and other major elements included $\mathrm{Mg}, \mathrm{K}, \mathrm{Na}, \mathrm{Fe}, \mathrm{Al}, \mathrm{Cu}, \mathrm{Zn}, \mathrm{Sr}, \mathrm{Ba}, \mathrm{Mn}$, and $\mathrm{Ti}$, whereas Ni, Cr, V, Ga, Mo, Co, Cd, etc. were found at trace levels $(<1 \mathrm{ng} / \mathrm{mg}$-weight). Internal As and $\mathrm{Ag}$ concentrations were dependent on the soil habitat. $\mathrm{Zn}$ concentration was maintained at a constant level as an essential element. The results suggest that the elemental contents of millipedes provide information on the accumulation and/or regulation mechanisms in the body for certain heavy metals, which would be useful information for environ- mental pollution studies.

\section{ACKNOWLEDGEMENTS}

We are grateful to Drs. A. Tokuyama and S. A. Vuai of the University of the Ryukyus for their helpful discussions regarding this paper. We would also like to thank Mr. S. Sakiyama (Okinawa Prefectural Enterprise Bureau) for his kind cooperation throughout this study.

\section{REFERENCES}

Beyer, W. N., O. H. Pattee, L. Sileo, D. J. Hoffman and B. M. Mulhern (1985) Metal contamination in wildlife living near two zinc smelters. Environ. Pollut. Ser. A 38: 63-86.

Bowen, H. J. M. (1979) [Asami, T. and M. Chino Japanese translation, 1983] Environmental Chemistry of the Elements. Hakuyû-sha, Tokyo. 159 pp.

Eisner, T., D. Alsop, K. Hicks and J. Meinwald (1978) Defensive secretions of millipedes. In Arthopod Venoms (S. Bettini ed.). Springer-Verlag, Berlin, pp. 41-72.

Gräff, S., M. Berkus, G. Alberti and H. R. Köhler (1997) Metal accumulation strategies in saprophagous and phytophagous soil invertebrates: a quantitative comparison. BioMetals 10: 45-53.

Hattori, K. and K. Moriya (1987) Fukaigaichu to Sono Kujyo, Gaichu Kujyo Series. Japan Environmental Sanitation Center, Kawasaki, pp. 114-118 (in Japanese).

Heikens, A., W. J. G. M. Peijnenburg and A. J. Hendriks (2001) Bioaccumulation of heavy metals in terrestrial invertebrates. Environ. Pollut. 113: 385-393.

Higa, Y., T. Kishimoto and K. Niijima (1992) Seasonal fluctuation of the Chamberlinius hualienensis Wang (Diplopoda: Strongylosomidae) on Okinawa Island. Annu. Rep. Okinawa Inst. Pub. Health 26: $42-49$ (in Japanese).

Hunter, B. A., M. S. Johnson and D. J. Thompson (1987) Ecotoxicology of copper and cadmium in a contaminated grassland ecosystem II. Invertebrates. J. Appl. Ecol. 24: 587-599.

Ireland, M. P. (1979) Metal accumulation by the earthworms Lumbricus rubellus, Dendrobaena veneta and Eiseniella tetraedra living in heavy metal polluted sites. Environ. Pollut. 19: 201-206.

Kawasaki, A., R. Kimura and S. Arai (1998) Rare earth elements and other trace elements in wastewater treatment sludges. Soil Sci. Plant Nutr. 44: 433-441.

Mori, N., Y. Kuwahara, T. Yoshida and R. Nishida (1994) Identification of benzaldehyde, phenol and mandelonitrile from Epanerchodus japonicus Carl (Polydesmida: Polydesmidae) as possible defense substances. Appl. Entomol. Zool. 29: 517-522.

Noguchi, S., N. Mori, Y. Higa and Y. Kuwahara (1997a) Identification of Nedyopus patrioticus patrioticus (Attems, 1898) (Polydesmida: Paradoxosomatidae) secretions as possible defense substances. Appl. Entomol. Zool. 32: 447-452.

Noguchi, S., N. Mori, Y. Higa and Y. Kuwahara (1997b) Identification of mandelonitrile as a major secretory com- 
pound from Chamberlinius hualienensis Wang (Polydesmida: Paradoxosomatidae). Jpn. J. Environ. Entomol. Zool. 8: 208-214.

Rabitsch, W. B. (1995) Metal accumulation in arthropods near a lead/zinc smelter in Arnoldstein, Austria. I. Environ. Pollut. 90: 221-237.

Roberts, R. D. and M. S. Johnson (1978) Dispersal of heavy metals from abandoned mine workings and their transference through terrestrial food chains. Environ. Pollut. 16: $293-310$.

Taira, J. and K. Arakaki (2002) Secretions of Chamberlinius hualienensis Wang (Polydesmida: Paradoxosomatidae) during the reproductive migration stage. Appl. Entomol. Zool. 37: 621-624.
Taira, J., K. Nakamura and Y. Higa (2003) Identification of secretory compounds from the millipede, Oxidus gracilis C. L. Koch (Polydesmida: Paradoxosomatidae) and their variation in different habitats. Appl. Entomol. Zool. 38: 401-404.

Teranishi, K., K. Isomura, M. Yano, H. Tsuji, K. Chayama, S. Fujiwara, K. Yao and H. Uchida (2003) Measurement of distribution of rare earth elements in Arima-type springs using preconcentration with chelating resin/ICPMS. Anal. Chem. 52: 289-296 (in Japanese with English summary).

Van Straalen, N. M. and J. Van Wensem (1986) Heavy metal content of forest litter arthropods as related to body-size and trophic level. Environ. Pollut. 42: 209-221. 